\title{
The Columbia River Research Laboratory
}

\section{The mission of the Columbia River Research Laboratory is to serve} the public by providing scientific information to support the stewardship of our Nation's fish and aquatic resources, with emphasis on the Columbia River basin. As a part of the U.S. Geological Survey (USGS) Western Fisheries Research Center, we conduct objective, relevant research and seek partnerships to help fulfill this mission.

\section{Who We Are}

The USGS Western Fisheries Research Center, Columbia River Research Laboratory (CRRL) was established in 1978 to address fishery issues in the Columbia River basin. Currently, the CRRL conducts research on fish and aquatic issues throughout the Columbia River basin and across the western United States. The CRRL is located in Cook, Washington, in the Columbia River Gorge east of Portland, Oregon.

A diverse and skilled group of Research Fishery Biologists, Fishery Biologists, Ecologists, Physiologists, Geographers, Biological Science Technicians, and administrative staff work at the laboratory year-round, and additional personnel work on a seasonal basis. The scientific staff serves on various regional committees and forums, design work groups for dam passage, interdisciplinary teams that address invasive species and climate change, endangered species recovery teams, watershed councils, advisory teams, and editorial boards. In addition to work within the Columbia River basin from headwater streams to the estuary, scientific staff actively collaborates with researchers from around the country and internationally. unbiased results and water managers.

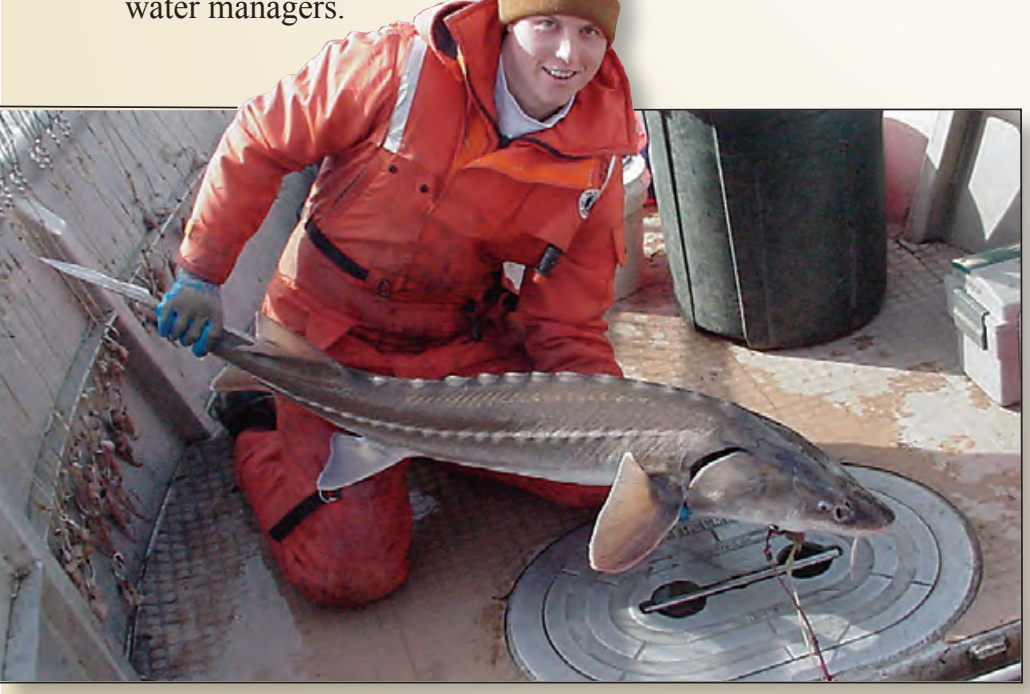

Researcher with white sturgeon (Acipenser transmontanus)
CRRL research projects include field, laboratory, and modeling studies on many topics:

- Behavior and survival of salmonids and other resident fishes

- Fish physiology

- Predation and species interactions

- Water quality effects on fish

- Habitat and bioenergetic modeling

- Evaluation of habitat restoration and environmental flows

- Effect of thermal stress on fish

- Large river ecology

- Invasive species

- Effect of climate change on fish populations and aquatic communities

- Spatial analysis and mapping (using GIS)

Juvenile Pacific lamprey (Lampetra tridentata)

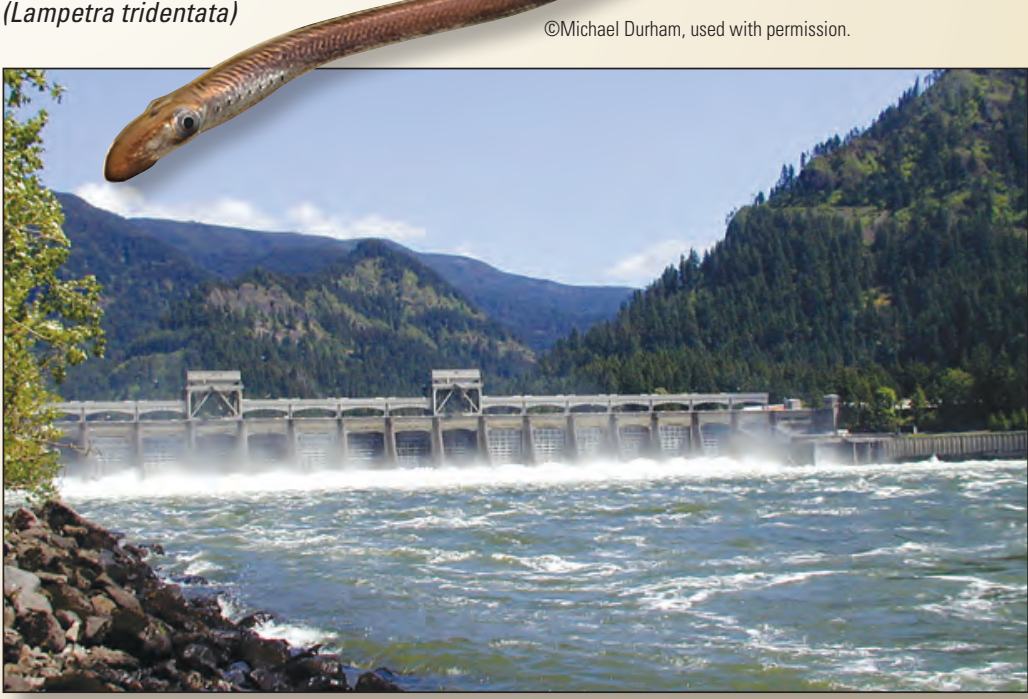

Bonneville Dam on the Columbia River 


\section{The Fish We Study}

Pacific salmon are the subject of many studies at CRRL, but projects also examine lamprey, sturgeon, bull trout, rainbow trout, resident fish, and exotic invasive species. For example, data are used to estimate movements and survival of juvenile salmon in rivers of the western United States, such as responses of fish to temperature stress and to restoration actions (dam passage modifications, dam removal, and stream restoration), and rates of predation on salmon. Models are developed to analyze habitat use by fish, responses of salmon to varying river flows, bioenergetics of fish, and to address potential implications of climate change on fish populations and aquatic communities.

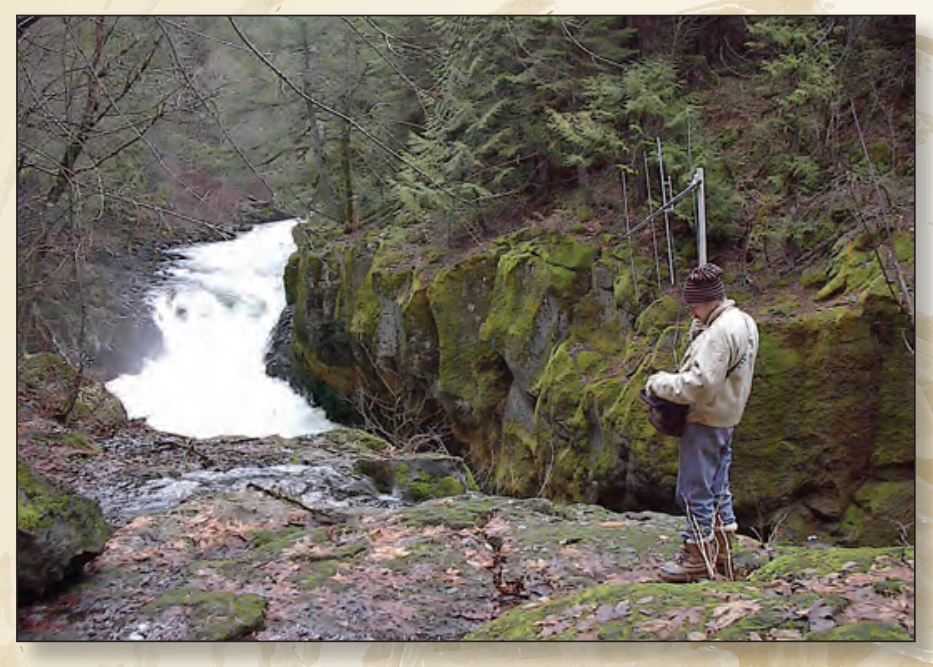

Tracking radio-tagged fish in a Columbia River tributary.

\section{Our Resources and Capabilities}

Field equipment includes a fleet of more than 40 research vessels as much as 30 feet in length. We sample the physical environment using acoustic water velocity profilers, single- and multi-beam acoustic instruments for bottomprofiling recording thermographs. We also collaborate with partners to conduct large-scale light detection and ranging (LIDAR) surveys. Large biotelemetry studies use radio and acoustic telemetry to assist in understanding the behavior and survival of fish. Three analytical laboratories at the CRRL are dedicated to enzymology, immunology and cell culture, and general physiology. A wet laboratory facility at CRRL is used for investigating fish development and behavior. The wet laboratory contains specialized equipment, such as predator-avoidance chambers, a thermalpreference gradient, and swim-tubes for testing swim performance and bioenergetics. Our science team is comprised of quantitative biologists who apply novel statistical, spatial, and simulation modeling techniques to fisheries and environmental data.

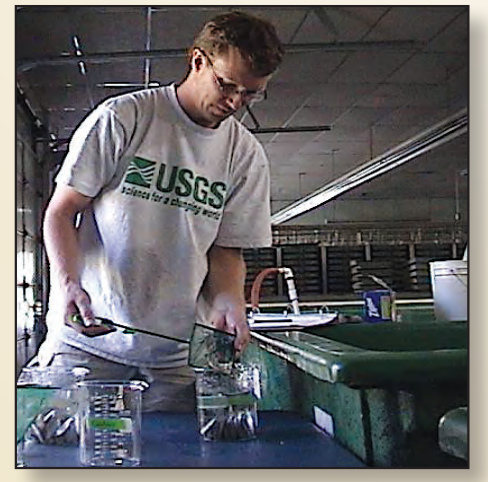

Sampling fish at U.S. Fish and Wildlife Entiat National Hatchery.

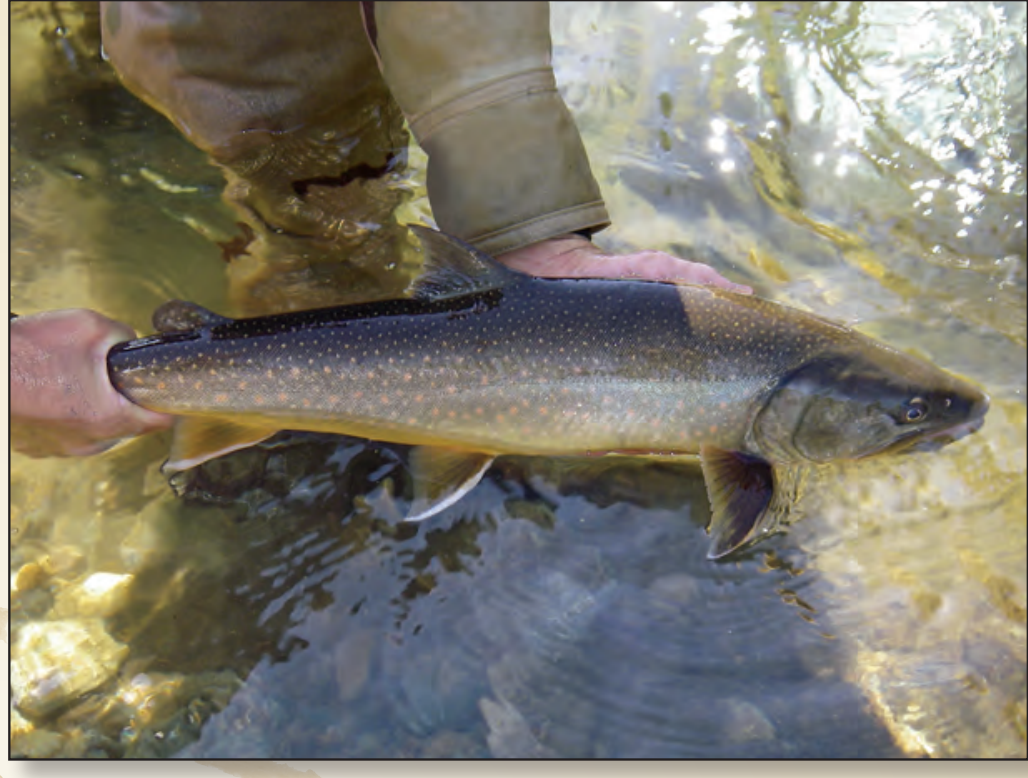

Adult bull trout (Salvelinus confluentus)

\section{Our Partners}

The CRRL collaborates with many partners throughout the western United States, including State, Federal, tribal, local, and academic institutions working with natural resources. These partners include Native American Tribes, the Bureau of Reclamation, the U.S Fish and Wildlife Service, the U.S. Army Corps of Engineers, and the Bonneville Power Administration.

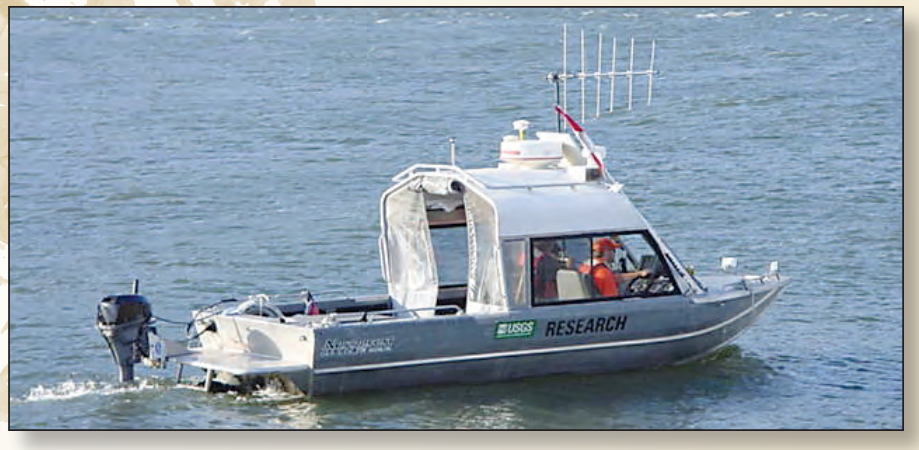

Boat-tracking juvenile salmon on the Columbia River.

Authors: Steve Waste and Rachel Reagan

For additional information contact:

Laboratory Director

U.S. Geological Survey

Western Fisheries Research Center

Columbia River Research Laboratory

5501A Cook-Underwood Road, Cook, WA 98605

(509) 538-2299 ext. 236 FAX (509) 538-2843

http://wfrc.usgs.gov

Photograph credits: Juvenile rainbow trout, Gary Winans, NOAA Fisheries; Pacific lamprey, Michael Durham Photography; all others, U.S. Geological Survey personnel.

Publishing support provided by the

U.S. Geological Survey

Tacoma Publishing Service Center 